\title{
Wiesław Skrzydło'
}

\section{Wojciech Zakrzewski ${ }^{2}$}

\section{Mała Konstytucja z dnia 19 lutego 1947 r. - geneza i znaczenie}

W bieżącym roku minęła 65 rocznica uchwalenia ustawy konstytucyjnej z dnia 19 lutego 1947 r. o ustroju i zakresie działania najwyższych organów Rzeczypospolitej Polskiej, potocznie zwanej Małą Konstytucją z 1947 r. Nie tylko upływ czasu dobrze służący ocenom najnowszej historii, ale i kolejne badania ustroju państwa w powojennej Polsce ${ }^{3}$ pozwalają na coraz pełniejsze poznanie przyczyn przyjęcia rozwiązań prawnych Małej Konstytucji i jej roli w kształtowaniu ustroju Polski Ludowej. Sprzyja to także weryfikacji szeregu tez i konkluzji na temat Małej Konstytucji, zwłaszcza że były one formułowane często $\mathrm{w}$ warunkach utrudniających dostęp do źródeł i w pełni otwartą prezentację wyników badań i ocen ${ }^{4}$. Powróciliśmy więc do dyskusji o uchwaleniu Małej Konstytucji jako początku pewnego etapu pośredniego pomiędzy Manifestem PKWN z dnia 22 lipca 1944 r. a Konstytucją PRL z dnia 22 lipca

1 Autor jest profesorem w Katedrze Prawa Konstytucyjnego Instytutu Administracji i Prawa Publicznego Wydziału Prawa i Administracji Uniwersytetu Marii Curie-Skłodowskiej w Lublinie.

2 Autor jest docentem w Katedrze Prawa Konstytucyjnego Instytutu Administracji i Prawa Publicznego Wydziału Prawa i Administracji Uniwersytetu Marii Curie-Skłodowskiej w Lublinie.

3 Por. przykładowo P. Czarny, Mała Konstytucja z 1947 r. a polska tradycja konstytucyjna, „Przegląd Sejmowy” 2007, nr 5; P. Borecki, Geneza Konstytucji PRL z 22 lipca 1952 r., „Przegląd Sejmowy” 2007, nr 5 oraz referaty i dyskusja na konferencji nt. Małe Konstytucje w historii ustroju państwa polskiego (1919-1947-1992), Warszawa, dnia 17 maja 2012 r.

4 O intencjach politycznych i oczekiwaniach „nowej władzy” w odniesieniu do Małej Konstytucji pisał A. Burda (jak się wydaje - w zawoalowany sposób): „Ramowość postanowień ustawy konstytucyjnej miała to znaczenie, że mogła ona ułatwić ewoluowanie ustroju politycznego i regulować go w drodze ustawodawstwa zwyczajnego dostosowanego do potrzeb rozwijającego się życia społecznego"; A. Burda, Polskie prawo państwowe, Warszawa 1977, s. 134. 
1952 r. ${ }^{5}$ oraz kwestii, czy Małą Konstytucję można uznać za element składowy polskiej tradycji konstytucyjnej rozumianej wartościująco, a nie tylko formalnojurydycznie. Wydaje się, że charakterystyka tej ustawy konstytucyjnej jako nominalnej, w dużej mierze pozornej i fasadowej ${ }^{6}$, a przez to będącej negatywnym wzorcem konstytucyjnym utrwali się w świadomości społecznej. Nie zwalnia to od poszukiwania i wyjaśniania jej genezy i znaczenia.

\section{I.}

Istotne znaczenie $\mathrm{w}$ procesie tworzenia aktów prawnoustrojowych państwa w latach 40 . miały takie dokumenty polityczne wydawane w okresie powstawania władzy ludowej jak: Uchwała KRN z dnia 1 stycznia 1944 r. „Statut tymczasowy rad narodowych", ustawa z dnia 21 lipca 1944 r. o utworzeniu Polskiego Komitetu Wyzwolenia Narodowego, Manifest tego komitetu z dnia 22 lipca 1944 r. ${ }^{7}$ Akty te, podobnie jak i inne dokumenty, zarówno o charakterze prawnym, jak i politycznym, świadczą o tym, że nowa władza powstawała nie w oparciu o obowiązujące dotychczas prawa, ale w drodze rewolucyjnej, tworząc nowe podstawy prawne swego istnienia.

Daje temu wyraz wspomniany Statut tymczasowy, który już w pierwszym zdaniu stwierdza, że „Moralno-prawną podstawą, na której powstają i opierają swą działalność rady narodowe jest wola szerokich mas polskich...", ale także: „demokratyczne zasady konstytucji marcowej z 1921 r. obalonej wbrew woli narodu...”. Powołanie się na wolę narodu, a nie na określony akt prawny, znajdujemy także w Manifeście PKWN, który stwierdza, iż KRN, „powołana przez walczący naród, jest jedynym legalnym źródłem władzy w Polsce"8. Istniejącemu w Londynie polskiemu rządowi emigracyjnemu twórcy Manifestu stawiają zarzut nielegalności.

5 Por. K. Działocha, Geneza konstytucji PRL, [w:] Konstytucja PRL po trzydziestu latach obowiązywania, red. K. Działocha, Wrocław 1983, s. 13 i n.

6 Jako jedna z pierwszych pisała o tym K. Kersten w pracy Narodziny systemu wtadzy. Polska 1943-1948, Warszawa 1985.

7 Akty te, jak też inne dokumenty mające decydujący wpływ na kształt tworzonego ustroju, zawiera książka opracowana przez A. Gwiżdża i J. Zakrzewską pt. Konstytucja i podstawowe akty ustawodawcze Polskiej Rzeczypospolitej Ludowej, wyd. III uzupełnione, Warszawa 1958.

8 Ibidem, s. 8. 
Tworząc PKWN jako „legalną, tymczasową władzę wykonawczą”, twórcy Manifestu deklarują, iż KRN i PKWN działają na podstawie Konstytucji z dnia 17 marca 1921 r.: ,jedynie obowiązującej konstytucji, legalnej, uchwalonej prawnie". Stwierdzenie to nie oznacza jednak, iż PKWN opowiada się za integralnym obowiązywaniem tej Konstytucji, bowiem następne zdanie zawiera wprost stwierdzenie, że obowiązują tylko „podstawowe założenia” tej Konstytucji i obowiązywać będą aż do zwołania wybranego Sejmu Ustawodawczego, który uchwali nową konstytucję . Stanowisko władz w tej sprawie nie zostało sprecyzowane wyraźnie - co stanowiło podstawę do rozbieżnych ocen zarówno w doktrynie prawa konstytucyjnego, jak i wśród polityków co do zakresu i sposobu obowiązywania założeń Konstytucji.

Wcześniejsza deklaracja tworzących się władz o ich rewolucyjnej genezie zostaje powtórzona w innym miejscu, bowiem Manifest PKWN nie szukał dla siebie i swego funkcjonowania prawnego uzasadnienia, stąd wynikało nawiązanie tylko do podstawowych założeń demokratycznej konstytucji. Jednak podstawowe założenia tej konstytucji mają obowiązywać nie siłą autorytetu, który ją uchwalał, ale siłą i wolą nowo tworzących się władz.

Odwołanie się do Konstytucji marcowej było względnie jednoznacznie oceniane w polskiej historiografii, bowiem, jak stwierdza K. Działocha, odwołanie się do Konstytucji z 1921 r. z jednoczesnym odrzuceniem Konstytucji kwietniowej z 1935 r., która stanowiła podstawę działania polskich władz emigracyjnych w Londynie, było szukaniem podstaw legalności nowej władzy „rewolucyjnego z natury pochodzenia”"10. Odrzucenie Konstytucji z 1935 r. służyło nowej władzy do kwestionowania legalności władz emigracyjnych, a tym samym braku legalności istnienia rządu emigracyjnego. Władza ludowa bez nawiązania do Konstytucji marcowej - jak pisze W. Góra - byłaby jedynie ciałem rewolucyjnym „sięgającym po władzę w drodze niejako zamachu stanu"11. Miało to również pozwolić jej na szukanie poparcia środowisk wrogich czy niechętnych sanacji, a więc było działaniem

\footnotetext{
9 Ibidem.

10 K. Działocha, Wstęp, [w:] K. Działocha, J. Trzciński, Zagadnienie obowiązywania Konstytucji marcowej w Polsce Ludowej 1944-1952, Wrocław-Warszawa-Kraków-Gdańsk 1977, s. 5.

11 W. Góra, Powstanie władzy ludowej w Polsce, Warszawa 1921, s. 77. Podobną ocenę tych decyzji podaje K. Kersten, PKWN 22 VII-31 XII 1944, Lublin 1965; Polska Ludowa 1944-1950. Przemiany społeczne, red. F. Ryszka, Wrocław-Warszawa-Kraków-Gdańsk 1974; M. Turlejska, Spór o Polskę. Szkice historyczne, Warszawa 1972, s. 328.
} 
taktycznym. Była więc próbą legitymizacji władzy w oparciu o założenia Konstytucji marcowej.

Nie rozwijając szerzej tego tematu, należy stwierdzić, że w świetle dokumentów KRN i PKWN w kwestii obowiązywania Konstytucji z 1921 r. w warunkach Polski Ludowej zaznaczyły się cztery stanowiska. Pierwsze, niezbyt rozpowszechnione, sprowadza się do stwierdzenia, że ustawa zasadnicza z 1921 r. obowiązywała w całości ${ }^{12}$, a spory dotyczyły nawet kwestii, czy obowiązywanie to obejmowało także postanowienia noweli sierpniowej z $1926 \mathrm{r}$.

Bardziej rozpowszechniony był pogląd oparty na deklaracjach władz Polski Ludowej o obowiązywaniu, zgodnie ze stanowiskiem Manifestu lipcowego, tylko podstawowych „demokratycznych” jej założeń. Słusznie dowodzi K. Działocha, że żaden akt prawny nie przywracał mocy prawnej całości przepisów Konstytucji z 1921 r., choć w niektórych aktach prawnych przywracano moc obowiązującą poszczególnym artykułom, czy ich grupom (jak normowała Mała Konstytucja z 1947 r.). Niekiedy czyniono to wprost w drodze praktyki.

Trzecia grupa poglądów dotyczyła kwestii czasu obowiązywania podstawowych założeń. Przeważa w doktrynie opinia, że podstawowe założenia tej konstytucji obowiązywały tylko do czasu zwołania Sejmu Ustawodawczego, a więc stanowisko to było oparte na założeniach Manifestu lipcowego ${ }^{13}$.

Istniał także pogląd, którego zwolennicy rozciągali ten okres na lata pełnej kadencji Sejmu Ustawodawczego.

W literaturze słusznie zarzuca się autorom tak zróżnicowanych poglądów, że nie uwzględniają istotnej kwestii, czyli stosunku treści podstawowych założeń Konstytucji marcowej do ustrojowej koncepcji KRN i SU, jak też do realizacji zasad prawnych ustroju Polski w latach 1944-1952, a zatem i praktyki ustrojowej w tym okresie ${ }^{14}$.

Podkreślić należy, że poza obowiązywaniem podstawowych założeń konstytucji z 1921 r. występowało w praktyce także inkorporowanie do treści

2 Zob. A. Mycielski, który głosił taką tezę, oczywiście wyłączając jako obowiązujące przepisy noweli sierpniowej z 1926 r.; Polskie prawo polityczne, cz. II (na drodze ku nowej konstytucji), Kraków 1948, s. 3; tenże, Prawo polityczne (Konstytucja z 17 marca 1921 r.), Kraków 1947, s. 8.

13 K. Działocha, Wstęp, [w:] K. Działocha, J. Trzciński, Zagadnienie obowiązywania..., s. $13-14$.

14 Można podać tytułem przykładu K. Biskupski, Zarys prawa państwowego Polskiej Rzeczypospolitej Ludowej oraz niektórych państw obcych, Warszawa 1962, s. 180. 
aktów prawnych (przykład Małej Konstytucji jest tu szczególnie wymowny) całych grup przepisów Konstytucji marcowej. Postępowano w ten sposób także w aktach prawnych niższej rangi, częste jest powtarzanie poszczególnych artykułów z aktów prawnych pochodzących z okresu II Rzeczypospolitej.

Ważne jest także, że zarówno podstawowe założenia, jak też powoływane w aktach prawnych $\mathrm{z}$ okresu działania KRN i SU poszczególne artykuły dawnego ustawodawstwa obowiązując w nowych warunkach historycznych były interpretowane i realizowane $\mathrm{w}$ zakresie, $\mathrm{w}$ jakim przywracała je do życia wola organów nowej władzy, a więc „odpowiednio do potrzeb nowego ustroju”. Powstanie rewolucyjne nowej władzy należy rozumieć tak, że nie była ona związana wcześniejszym porządkiem prawnym obowiązującym w Polsce.

Nie wchodząc w szczegółowe rozważania dotyczące zarówno kształtu tych zasad i ich rozwinięcia w Małej Konstytucji ${ }^{15}$, warto zwrócić uwagę, że już na gruncie samej konstytucji zasady te ulegały daleko idącej modyfikacji a w gruncie rzeczy deformacji. Poza literalnym nawiązaniem do trójpodziału władzy nie został przeprowadzony dostateczny rozdział personalny i funkcjonalny głównych władz, a tym bardziej trudno było się dopatrzeć mechanizmów ich równoważenia. Zerwawszy z tradycją dwuizbowości parlamentu, Sejm Ustawodawczy uzyskał pozycję formalnie wykraczającą poza ramy mechanizmu rządów parlamentarnych, co służyć miało budowaniu podwalin pod wprowadzoną w konstytucji PRL zasadę jednolitości władzy państwowej. Stworzenie instytucji Rady Państwa i zakwalifikowanie jej jako organu władzy wykonawczej, szczególne umocowanie prezydenta jako przewodniczącego Rady Państwa i konstytucyjnego organu w postaci Rady Gabinetowej czy marginalizacja pozycji NIK to tylko przykłady przeistaczania zasad demokracji konstytucyjnej w jej namiastki. Fasadowa, a w praktyce fikcyjna, okazała się zapowiedź realizacji podstawowych praw i wolności gwarantowanych Konstytucją marcową. Uchwalona w tej mierze Deklaracja stanowiła in fine, że ustawy winny zapobiegać „wyzyskiwaniu praw i wolności do walki z demokratycznym ustrojem Rzeczypospolitej Polskiej”, a więc zasada wolności jednostki została zastąpiona ideologicznym dyktatem nowej władzy.

15 K. Działocha, Wstęp, [w:] K. Działocha, J. Trzciński, Zagadnienie obowiązywania..., s. 15. 
II.

Występuje w literaturze pogląd, że wpływ zasad Konstytucji marcowej na instytucje ustrojowe Polski Ludowej znacznie silniej zaznaczał się w okresie Sejmu Ustawodawczego niż w latach Krajowej Rady Narodowej. Zjawisko to uwidacznia się w najwyższym stopniu w aktach prawnych rangi konstytucyjnej uchwalonych w lutym 1947 r. Chodzi tu o ustawę konstytucyjną z dnia 4 lutego 1947 r. o wyborze prezydenta Rzeczypospolitej, o ustawę konstytucyjną z dnia 19 lutego 1947 r. o ustroju i zakresie działania najwyższych organów Rzeczypospolitej Polskiej, a także w akt prawny niższej rangi, jakim była Deklaracja Sejmu Ustawodawczego z dnia 22 lutego 1947 r. w przedmiocie realizacji praw i wolności obywatelskich.

Szukając odpowiedzi na pytanie dotyczące wskazania, w jakim stopniu widoczny był wpływ Konstytucji marcowej na treść wymienionych ustaw wskazać należy na odniesienie się do zasad:

a) zwierzchnictwa narodu,

b) parlamentarno-gabinetowego systemu rządów,

c) podziału władzy,

d) deklaracji wolności i praw jednostki.

Treść wymienionych aktów prawnych pozwala ustalić tak zakreślony katalog. Podchodząc jednak do tej kwestii nie od strony czysto formalnej, ale uwzględniając również praktykę i stanowisko władz Polski Ludowej w całym okresie 1944-1952, nie można nie podzielić poglądu A. Burdy, który podkreślał, że wpływ Konstytucji marcowej na ustrój polityczny państwa w okresie Sejmu Ustawodawczego był bardziej pozorny niż rzeczywisty. Dostrzega się go tylko stosując ograniczoną, formalną i wybiórczą analizę przepisów prawa. W rzeczywistości, przeprowadziwszy bardziej wnikliwą analizę praktyki, dojść należy do wniosku, że przemiany zachodzące w państwie po 1947 r. wyraźnie zbliżają, zarówno strukturę, jak i funkcje tak nowego, jak i reformowanego aparatu państwowego do modelu państwa radzieckiego. Słusznie zatem podkreśla J. Trzciński, że wpływ Konstytucji marcowej po 1947 r. można uznać za mało znaczący, że był on w istocie jednorazowy, gdyż ujawniał się w sposób wyraźny tylko w aktach prawnych rangi konstytucyjnej uchwalonych w początkach roku 1947 - a w okresie późniejszym już nie był widoczny ${ }^{16}$.

\footnotetext{
16 Ibidem.
} 
Charakteryzując obowiązujące po 1947 r. przepisy prawa, należy dojść do wniosku, że mamy do czynienia z pewną wyraźną specyfiką, wyróżniającą naszą sytuację w skali państw demokracji ludowej. W Polsce nie doszło do generalnego uchylenia przedwrześniowych aktów normatywnych. Przestały obowiązywać stosunkowo nieliczne akty pozostające w wyraźnej sprzeczności z nowym ustrojem, jego podstawowym dokumentami. Tytułem przykładu podać można uchylenie ustawy o Policji Państwowej, zastąpionej dekretem o utworzeniu Milicji Obywatelskiej z dnia 7 października 1944 r. Nie były to przypadki liczne, a zdecydowana większość aktów normatywnych sprzed 1939 r. stanowiła nadal podstawę prawną działania wielu organów i instytucji państwowych. Stosowane w tym względzie kryteria to ocena, czy akty te nie stoją w sprzeczności z zasadniczym kierunkiem ewolucji ustroju państwa. Zmianom ulegały przepisy z zakresu ustroju politycznego, głównie dotyczące organizacji i kompetencji naczelnych i terenowych organów władzy państwowej i samorządu terytorialnego.

Najpilniejsza potrzeba uchwalenia nowego aktu konstytucyjnego wiązała się z wygaśnięciem z dniem wyborów, a więc już dnia 19 stycznia 1947 r. kompetencji KRN, a z dniem zebrania się Sejmu Ustawodawczego na pierwsze posiedzenie w dniu 4 lutego 1947 r. wygasły kompetencje prezydenta KRN. Dlatego już dnia 4 lutego została uchwalona ustawa konstytucyjna o wyborze Prezydenta Rzeczypospolitej.

Z punktu widzenia analizowanej problematyki szczególna rola przypada art. 1 Małej Konstytucji. Określa on ważną kwestię dotyczącą podmiotu zwierzchniej władzy w państwie, a więc jednej z podstawowych zasad Konstytucji z 1921 r. Określenie to znalazło wyraz w pierwszym zdaniu art. 1 omawianej ustawy konstytucyjnej. Powołując się w tymże artykule na zasadę „Zwierzchniej władzy narodu Polskiego”, wskazuje suwerena. Ustawa konstytucyjna, nie wymieniając wprost zasady zwierzchnictwa narodu, formułuje ją pośrednio w drodze użycia określenia władzy zwierzchniej narodu. Ustawodawca w tymże artykule powołuje się jeszcze na podstawowe założenia Konstytucji marcowej, na Manifest PKWN i na wyniki głosowania ludowego z dnia 30 czerwca 1946 r.

Mała Konstytucja podkreśla dwie cechy charakteryzujące ten akt normatywny. Pierwsza - to jej przejściowy, tymczasowy charakter - ma obowiązywać „do czasu wejścia w życie nowej Konstytucji”. Cecha druga została wyrażona w tytule ustawy konstytucyjnej z dnia 19 lutego 1947 r., a jest 
nią niepełność zawartych w tym akcie regulacji prawnych. W tytule podkreślono, iż ustawa ta reguluje ustrój i zakres działania najwyższych organów Rzeczypospolitej Polskiej. Kwestie te regulowano dwojakiego rodzaju normami. Pierwsza grupa regulacji prawnych to przepisy stanowiące twór oryginalny, są to nowe zupełnie przepisy powstałe w toku prowadzonych w Sejmie Ustawodawczym prac legislacyjnych. Grupa druga obejmuje przepisy prawne inkorporowane do Małej Konstytucji, a przejęte z tekstu Konstytucji marcowej, które moc obowiązującą otrzymały z woli i decyzji Sejmu Ustawodawczego. Przepisy należące do tej grupy regulowały następujące kwestie: a) dotyczące posłów (zawarte w art. 21, 22 i 24 Konstytucji z 1921 r.), b) prezydenta Rzeczypospolitej Polskiej (art. 40, 42, 43, 44, 45 ust. 2-46, 47, 48, 49, 50, 51, 52 i 53), a także c) Rady Ministrów (art. $44-45$ ust. 1 i 2 oraz art. 56-63 Konstytucji marcowej).

Fakt, że nie cała struktura organów władzy państwowej została uregulowana w drodze przepisów Małej Konstytucji, jest dowodem na potwierdzenie tezy o fragmentaryczności tego aktu prawnego - jego niepełności, co jest charakterystyczne właśnie dla aktów normatywnych określanych mianem małych konstytucji.

Ustawa konstytucyjna z dnia 19 lutego 1947 r. uchwalona została przez Sejm Ustawodawczy w atmosferze sporów i walk politycznych ugrupowań lewicowych z opozycją PSL. Opozycja zarzucała ugrupowaniom lewicy, że treść art. 2. Małej Konstytucji deklarujący zasadę podziału władzy wykracza poza ramy tej zasady i nie daje się pogodzić z jej istotą. Po pierwsze, nie jest do pogodzenia z tą zasadą skład organów zaliczanych do władzy wykonawczej. Art. 2 do organów zaliczanych do tej władzy wprowadził prezydenta Rzeczypospolitej i Radę Ministrów, co jest zrozumiałe i nie budzi zastrzeżeń. Natomiast zastrzeżenia wywołuje zaliczenie do organów władzy wykonawczej Rady Państwa, w skład której wchodzili - obok prezydenta RP także marszałek sejmu i wszyscy wicemarszałkowie reprezentujący wszak władzę ustawodawczą. Wchodził także prezes Najwyższej Izby Kontroli, którego trudno zakwalifikować jako przynależnego do władzy wykonawczej.

Po drugie - nie do pogodzenia $\mathrm{z}$ istotą zasady podziału władzy, zakładającej wszak ich równowagę, jest określenie w art. 1 Małej Konstytucji ustawowej roli Sejmu Ustawodawczego jako organu najwyższego, będącego organem władzy zwierzchniej narodu, której to cechy nie przyznano organom zaliczanym do pozostałych władz. 
Stanowisko doktryny w kwestii obowiązywania tej zasady w świetle Małej Konstytucji jest wyraźnie zróżnicowane. Najbliższe jej istoty jest stanowisko opowiadające się za generalnym obowiązywaniem tej zasady. Jak podkreśla K. Działocha ${ }^{17}$, stanowisko to cechuje przyjmowanie zasady podziału władzy w formie złagodzonej w porównaniu z przepisami zawartymi w Konstytucji marcowej. Zwolennicy tego poglądu sformułowali to stanowisko w nawiązaniu do podstawowych założeń Konstytucji z 1921 r. i przyjęli pogląd wyrażany przez twórców tej ustawy konstytucyjnej w art. 2.

Drugi pogląd charakteryzujący się kompromisowym ujęciem kwestii skupiał najliczniejszą grupę, a K. Grzybowski nazwał przyjęty system systemem mieszanym ${ }^{18}$. Dopatrywano się w nim elementów spotykanych w stanowisku konstytucji socjalistycznych.

Pogląd trzeci jest najdalej idący, a jego głównym rzecznikiem był S. Rozmaryn $^{19}$, przytaczający głównie argumenty prawne. Stał on na stanowisku oznaczającym całkowite odrzucenie zasady podziału władzy w strukturze organów państwa. Opowiadał się na rzecz jednolitości władzy państwowej, dostrzegał i dopuszczał tylko podział kompetencji organów państwa.

Analizując przebieg dyskusji parlamentarnej w toku prac legislacyjnych i uchwalania Małej Konstytucji, K. Działocha dochodzi do wniosku, że większość Sejmu Ustawodawczego stała na stanowisku społeczno-politycznej jedności władzy państwowej, powstałej w wyniku zmian dokonywanych w sferze społeczno-ekonomicznej i politycznej, że w oparciu o faktyczną jedność naczelnych organów państwowych tworzono ustrój zrywający z zasadą podziału władzy ${ }^{20}$.

Pogląd taki reprezentował także E. Zwierzchowski, stojąc na stanowisku, że zasada podziału władzy została tylko formalnie przyjęta w Małej Konstytucji, przy czym jej autorzy wnieśli pewne modyfikacje, które połączone zostały z politycznymi uwarunkowaniami systemu partyjnego, co $\mathrm{w}$ istot-

\footnotetext{
17 K. Działocha, Sejm ustawodawczy jako organ zwierzchni władzy narodu, [w:] Sejm Ustawodawczy Rzeczypospolitej Polskiej 1947-1952, red. M. Rybicki, Wrocław-Warszawa-Kraków-Gdańsk 1977, s. 94.

18 K. Grzybowski, Ustrój Polski wspótczesnej 1944-1948, Kraków 1948, s. 134-135.

19 S. Rozmaryn, W jakim zakresie obowiązuje dziś Konstytucja z 17 marca 1921 r., „Państwo i Prawo” 1948, nr 1, s. 20.

20 K. Działocha, Sejm ustawodawczy jako organ zwierzchni władzy narodu, [w:] Sejm Ustawodawczy, op.cit., s. 100.
} 
ny sposób zmodyfikowało prawnie określony mechanizm funkcjonowania przyjętego systemu ${ }^{21}$.

Kolejną z zasad ustrojowych, czyli jednym z podstawowych założeń Konstytucji marcowej, był parlamentarno-gabinetowy system rządów. Zasadę tę w sposób wyraźny i niekwestionowany odnajdujemy w treści ustawy konstytucyjnej z dnia 19 lutego. Określała ona stosunki w zakresie relacji między parlamentem, głową państwa i rządem. Tak również formalnie obowiązujący system przyjęto, choć podlegał on także istotnym modyfikacjom. Wyrażały się one w tym, że tekst Małej Konstytucji określał przede wszystkim formy nadrzędności Sejmu Ustawodawczego wobec Rady Ministrów, a w mniejszym stopniu wobec prezydenta Rzeczypospolitej. Wyraźnie dostrzega się, że w ustroju władz pozycję Sejmu Ustawodawczego określały nowe mechanizmy, które w sposób oczywisty różniły się od zasady podziału władzy. Świadczą o tym konsekwencje wynikające z wprowadzenia do struktury naczelnych organów państwa Rady Państwa, a także połączenie tego organu z osobą prezydenta Rzeczypospolitej, stojącą na czele tego nowego organu.

Podkreślić nadto należy, że pewne kompetencje, które tradycyjnie należały do Rady Ministrów Mała Konstytucja powierzyła i rządowi, i Radzie Państwa (np. prawo inicjatywy ustawodawczej, powiązanie prawa wydawania dekretów z mocą ustawy z zatwierdzaniem ich przez Radę Państwa). Oznaczało to wprowadzenie kontroli Rady Ministrów nie tylko przez Sejm Ustawodawczy, ale także przez Radę Państwa.

Nie był to przy tym jedyny wyłom w klasycznej postaci systemu parlamentarno-gabinetowego, gdyż w Małej Konstytucji uległa zmianie pozycja ustrojowa prezydenta Rzeczypospolitej. Uzyskał on nowe uprawnienia związane z przewodniczeniem obradom Rady Ministrów, przewodniczył Radzie Państwa, jak również Radzie Gabinetowej (posiedzenie Rady Ministrów odbywające się pod przewodnictwem prezydenta Rzeczypospolitej). Uzyskał zatem duży wpływ na działalność wymienionych organów.

Istota systemu parlamentarno-gabinetowego obejmuje m.in. kontrolę parlamentarną naczelnych organów, stąd wynikało przyjęcie w Małej Konstytucji instytucji kontrasygnaty aktów głowy państwa przez członków Rady Ministrów, którzy tym samym biorą na siebie odpowiedzialność przed Sej-

21 E. Zwierzchowski, Polityczny proces ksztaltowania ustroju Polski Ludowej 1944-1952, Katowice 1981, s. 115. 
mem za wydane akty urzędowe. Mała Konstytucja utrzymała tę zasadę, ale nie wprowadziła kontrasygnaty aktów prezydenta wydawanych w charakterze przewodniczącego Rady Państwa i w Radzie Gabinetowej, co świadczy o dużym odstępstwie od klasycznej postaci systemu rządów parlamentarnych. Tym samym doszło w Małej Konstytucji do wyraźnego upolitycznienia stanowiska ustrojowego głowy państwa. Ponieważ prezydent od $1948 \mathrm{r}$. łączył w sobie przywództwo partii rządzącej, czyli PZPR, mamy do czynienia $z$ wyraźnym odchodzeniem od systemu parlamentarno-gabinetowego w omawianym okresie.

Inne uprawnienia głowy państwa wynikające $\mathrm{z}$ formalnego tylko przyjęcia w Małej Konstytucji zasady systemu parlamentarno-gabinetowego Mała Konstytucja przejęła z Konstytucji 1921 r. i były w praktyce przez prezydenta wykonywane.

Jednak jeśli obok wymienionych modyfikacji omawianego systemu rządów uwzględnimy jeszcze fakt wyeliminowania w parlamencie opozycji politycznej, to rodzi się kwestia, czy istnienie tak wielu zmian pozwala jeszcze uznawać ówczesny system rządów za system parlamentarno-gabinetowy. Wątpliwość ta wzrasta jeszcze bardziej, gdy uwzględni się fakt, że art. $13 \mathrm{Ma}$ łej Konstytucji pozwala inkorporowane przepisy Konstytucji marcowej stosować nie w całej rozciągłości, a „odpowiednio”.

Analizując omówione modyfikacje w zakresie prawnych regulacji określających przyjęty w Małej Konstytucji system rządów, uwzględnić trzeba dokonywane od 1947 r. zmiany natury społeczno-politycznej, m.in. faktyczną likwidację opozycyjnego PSL sterowane zjednoczenie partii robotniczych w 1948 r., a w roku 1949 także ruchu ludowego. Te i tym podobne wydarzenia, jak też omówione zmiany prawnej natury, uczyniły - jak stwierdza K. Działocha - polską konstrukcję prawną systemu parlamentarno-gabinetowego praktycznie martwą.

Kolejnym podstawowym założeniem Konstytucji marcowej, w specyficzny sposób unormowanym w okresie Małej Konstytucji, była Deklaracja Sejmu Ustawodawczego z dnia 22 lutego $1947 \mathrm{r}$. w przedmiocie realizacji praw i wolności obywatelskich, nie była to wprawdzie ustawa konstytucyjna, nie była nawet ustawą zwykłą, była to deklaracja, a więc akt niemający mocy powszechnie obowiązującej, niepodlegający ogłoszeniu w Dzienniku Ustaw RP. Był to akt samozobowiązania się Sejmu Ustawodawczego, że organ ten $\mathrm{w}$ toku swych prac konstytucyjnych i ustawodawczych oraz w toku kontro- 
lowania rządu i ustalania zasadniczej linii polityki państwa będzie kontynuować realizację podstawowych praw i wolności obywatelskich.

Zawarty w deklaracji katalog wolności i praw jednostki nawiązuje do treści rozdziału V Konstytucji marcowej, ale jest skromniejszy. Brakuje w szczególności kilku ważnych praw, a mianowicie prawa do sądu (art. 98 Konstytucji marcowej) oraz prawa do wynagrodzenia szkody wyrządzonej wskutek działalności organów państwowych (art. 119), a także uznania wszelkiej własności (art. 99) i wolności prasy wraz z zakazem wprowadzania cenzury (art. 105).

Wprowadzono natomiast zakaz wykorzystywania praw i wolności obywatelskich do walki z demokratycznym ustrojem państwa, czemu winny zapobiegać ustawy.

\section{III.}

Mała Konstytucja nie określała okresu jej obowiązywania. Jednak z przyjętego w art. 1 stanowiska, iż „akt ten obowiązuje do czasu wejścia w życie nowej Konstytucji”, wynikało, że zadanie to winno być wykonane do dnia 3 lutego 1952 r. Wynika to stąd, że początek kadencji Sejmu Ustawodawczego przypadł w dniu 4 lutego 1947 r., kadencja miała trwać pięć lat zgodnie z art. 6. Nie był to Sejm zwykły, co podkreślała już jego nazwa, bowiem w polskiej tradycji Sejm uchwalający konstytucję był nazywany Sejmem Ustawodawczym (tak było w roku 1919). Określony zaś w art. 3 zakres działania Sejmu Ustawodawczego na pierwszym miejscu wymienia uchwalenie Konstytucji Rzeczypospolitej Polskiej.

Pięcioletnia kadencja upływała zatem dnia 3 lutego 1952 r. i jak z kalendarza wynika - w tym okresie zadanie podstawowe Sejmu nie zostało wykonane. Przyczyny takiej sytuacji były złożone i stanowiły rezultat działania skomplikowanych czynników społeczno-politycznej natury.

Po drugiej wojnie światowej Polska wraz z innymi państwami Europy Środkowej i Wschodniej, określanymi wówczas państwami demokracji ludowej, znalazła się w sferze dominacji Związku Radzieckiego. Według głoszonego wówczas poglądu, państwa te stanowić miały trzecią, obok kapitalistycznej i socjalistycznej, drogę rozwoju społeczeństwa i państwa. Były to zarazem lata, gdy - poza Polską - wszystkie te państwa dopracowały się kon- 
stytucji, poczynając od 1946 (Albania) do 1949 r. (NRD). Polska doczekała się uchwalenia nowej Konstytucji dopiero w połowie $1952 \mathrm{r}$.

Przyczyny tak rozumianego opóźnienia były natury złożonej, miały charakter polityczny i ideologiczny, bowiem dotyczyły ustalenia istoty panującego ustroju. Doszło do tego dopiero w końcu lat czterdziestych, a wiązało się to ściśle $\mathrm{z}$ toczącymi się w połowie grudnia 1948 r. obradami Kongresu Zjednoczeniowego partii politycznych polskiej lewicy (PPR i PPS). Na tym właśnie zjeździe poddano gruntownej krytyce teorie o polskiej drodze do socjalizmu, przeprowadzono zasadnicze zmiany personalne w kierownictwie partii spełniającej kierowniczą funkcję w państwie, dokonano ustalenia istoty klasowej państwa demokracji ludowej.

Odpowiedź na to zasadnicze pytanie znalazła się w referatach wygłoszonych na Kongresie przez B. Bieruta z ramienia PPR i J. Cyrankiewicza z ramienia PPS. Kongres stanowił wydarzenie o znaczeniu nie tylko organizacyjnym, ale przede wszystkim politycznym i ideologicznym. Powstała na Kongresie Polska Zjednoczona Partia Robotnicza, a Kongres uchwalił dokumenty o znaczeniu ważnym nie tylko dla partii, jej doktryny, ideologii i celów działania. W dokumentach tych znajdujemy nowe, zasadnicze określenie istoty państwa demokracji ludowej. Odrzucona została teza o polskiej drodze do socjalizmu. Na pytanie zaś o to - czym jest to państwo, jaka jest jego istota - odpowiedź B. Bieruta w jego referacie zawarta była jednoznaczna, że jest to państwo dyktatury proletariatu, a więc takie, jakie zbudowane zostało w Związku Radzieckim.

Stwierdzenie to miało kapitalne znaczenie dla przyszłych prac nad nową Konstytucją Polski Ludowej. Z przyjętego na Kongresie Zjednoczeniowym stanowiska jednoznacznie wynikało, że wzorca dla polskich regulacji konstytucyjnych nie należy szukać w światowym dorobku konstytucjonalizmu, ale że przyszła polska konstytucja ma być oparta na modelu radzieckim, że przykładem do naśladowania mają być nie ustawy zasadnicze demokracji zachodnich, ale wzorce mają pochodzić z państw obozu socjalistycznego, gdzie takie konstytucje powstawały w latach 40. XX wieku i oparte były na Konstytucji ZSRR z 1936 r. Należało się wzorować zatem na konstytucji zwanej stalinowską. Te wydarzenia spowodowały, że drogi do prac konstytucyjnych stanęły otworem.

Pisząc o pracach konstytucyjnych w Polsce, należy uwzględniać i osobno przedstawić dwie ich płaszczyzny, jedna to płaszczyzna partyjna, a więc 
działania prowadzone w łonie PZPR, druga zaś to płaszczyzna parlamentarna.

Prace partyjne prowadzono w ciszy gabinetów, bez nadawania przygotowaniom rozgłosu. Toczyły się w środowisku partyjnym, w ramach ciał i instytucji powołanych przez PZPR. Komisje te (w sumie dwie) do spraw ideologicznych i właściwa komisja merytoryczna rozpoczęły prace już w 1949 r. Druga płaszczyzna parlamentarna, w ramach której działała Komisja Konstytucyjna powołana przez Sejm Ustawodawczy, rozpoczęła prace dopiero $\mathrm{w}$ połowie $1951 \mathrm{r}$.

Jest rzeczą charakterystyczną i jednocześnie w pełni zrozumiałą w świetle represji wobec przeciwników socjalistycznych przemian ustrojowych, że w okresie tym nie dostrzegało się jakiegoś ożywienia dyskusji konstytucyjnej, nie pojawiały się samorzutnie przygotowywane (jak w latach 90.) projekty konstytucji propagowane wśród społeczeństwa. Pojawiały się tylko pewne postulaty, które mogły być brane pod uwagę w toku prac konstytucyjnych. Postulaty takie A. Gwiżdż omawia w trzech grupach ${ }^{22}$. Pierwsza z nich obejmowała postulaty wywodzące się z kręgów Kościoła katolickiego w postaci memoriału biskupów polskich wręczonego dnia 14 marca $1947 \mathrm{r}$. prezesowi Rady Ministrów.

Druga grupa postulatów wywodziła się z kręgów ówczesnej opozycji politycznej, głównie ze środowiska PSL. Trzecia grupa odegrała największą rolę i wywarła wpływ na tok prac Komisji konstytucyjnych i treść zgłaszanych propozycji w tym zakresie, wywodziła się z kręgów obydwu partii robotniczych, a następnie z PZPR.

Nurt ten odegrał szczególnie ważną rolę po Kongresie Zjednoczeniowym PZPR, gdyż po uzyskaniu materiałów kongresowych wiele pytań natury ideologicznej i politycznej tam uzyskano. To właśnie w środowisku tej partii koncentrowały się prace konstytucyjne. To w tym środowisku natężenie tych prac było widoczne, miały one przy tym charakter prac wyprzedzających w sposób istotny działalność w tym zakresie prac prowadzonych w kręgach parlamentarnych.

Ważny i godny odnotowania fakt dla zobrazowania prac przygotowawczych stanowiła uchwała Sekretariatu KC PZPR z czerwca 1949 r., na podstawie której utworzone zostały wspomniane już obie komisje KC do spraw

22 A. Gwiżdż, Organizacja i tryb przygotowania i uchwalenia Konstytucji Rzeczypospolitej Ludowej, [w:] Sejm Ustawodawczy, op.cit., s. 304-307. 
opracowania zasad projektu nowej konstytucji. Przewodniczącym obydwu tych komisji został członek Biura Politycznego KC Minister Sprawiedliwości Henryk Świątkowski.

Jedna $\mathrm{z}$ tych komisji miała roboczy charakter, jej zadaniem było przygotowanie odpowiednich materiałów w postaci referatów, także wniosków. Komisja ta była oznaczona literą $\mathrm{A}$.

Komisja B natomiast została pomyślana jako komisja ideologiczna, której zadaniem było przygotowanie materiałów do rozstrzygnięć natury ideologicznej przez kierownicze instancje PZPR. W skład tych dwu komisji wchodziło m.in. dwu profesorów prawa konstytucyjnego: K. Grzybowski i S. Rozmaryn, a także ówczesny sekretarz Rady Państwa, a późniejszy profesor prawa konstytucyjnego Marian Rybicki. Komisje te rozpoczęły prace w dniu 21 czerwca 1949 r.

Wstępne ustalenia przewidywały dla Komisji rozpatrzenie kwestii, czy konstytucja ma stanowić podsumowanie osiągnięć, czy zawierać także wytyczne dalszych przemian, a także rozważyć kwestie gospodarcze, społeczne i polityczne wymagające uregulowania w przyszłej konstytucji, zebranie materiałów porównawczych dotyczących kwestii konstytucyjnych innych państw itp. W tym celu na posiedzeniu komisji były przygotowywane przez członków referaty dotyczące np. kwestii naczelnych organów państwa te referował S. Rozmaryn - oraz sprawy praw i wolności obywatelskich K. Grzybowski.

Jest rzeczą charakterystyczną, że w toku prowadzonych dyskusji w łonie komisji dostępne materiały nie wykazują prób nawiązywania do doświadczeń z okresu obowiązywania Małej Konstytucji z 1947 r. Świadczy to wymownie, że jej regulacje prawne nie stanowiły przedmiotu dyskusji na posiedzeniach, zatem nie wywierały większego wpływu na tok tych prac. $\mathrm{Z}$ materiałów archiwalnych wynika, iż większą rolę odgrywały nowe propozycje rozwiązań ustrojowych i wyniki dyskusji prowadzonych w tym zakresie. Jak stwierdził A. Gwiżdż, „Wyrazem nowej koncepcji roli Sejmu w ustroju państwa winna być koncentracja jego aktywności na bardziej ogólnych problemach, uproszczenie procedury, częstsze realizowanie koncepcji prawotwórczych nie w drodze ustawodawstwa, lecz w innych formach, przez rozluźnienie sejmowej kontroli działalności rządu itp. Zgłaszane postulaty pod adresem rządu szły w podobnym kierunku. Wyrazem nowej koncepcji było skoncentrowanie w Radzie Ministrów i w jej ścisłym kierownictwie sze- 
rokiego zakresu kompetencji, w dużej mierze nie podlegającej kontroli społecznej władzy politycznej i gospodarczej. Zadanie to wykonywał rząd, bądź coraz częściej jego ścisłe kierownictwo ukonstytuowane od połowy $1950 \mathrm{r}$. jako Prezydium Rządu, działające pod przewodnictwem Prezydenta RP. Stworzono także organ scentralizowanego zarządzania gospodarką narodową w postaci Państwowej Komisji Planowania Gospodarczego.

Dyskutowano także o sprawach dotyczących administracji terenowej, o aparacie wymiaru sprawiedliwości, które to kwestie uległy zmianom ustawodawczym z roku 1949 i 1950.

Ustawy powstałe $\mathrm{w}$ wyniku pojawienia się nowych tendencji wynikających $\mathrm{z}$ wprowadzania nowych zasad ustrojowych państwa to akty wyprzedzające uchwalenie nowej konstytucji. Ustawa zasadnicza z roku 1952 stanowiła w dużym stopniu petryfikację tego właśnie ustawodawstwa. Znalazło to wyraz w rozdziałach o radach narodowych, o sądach i prokuraturze. Treści tych rozdziałów stanowiły rezultat nawiązania do widzenia nowego aparatu państwa jako aprobowania struktury aparatu państwowego wzorowanego na rozwiązaniach państwa socjalistycznego.

Podobnie rzecz się miała z regulacją, zepchniętych do rozdziału VII Konstytucji PRL, podstawowych praw i wolności obywatelskich. Tak jak w okresie obowiązywania Małej Konstytucji, gdy o statusie obywatela rozstrzygało bieżące ustawodawstwo, tak i na gruncie Konstytucji lipcowej relację jednostka-państwo kształtować miał ustawodawca zwykły. Do niego bowiem należało „kształtowanie i umacnianie” ustroju społeczno-gospodarczego i politycznego państwa, którego funkcją były - zgodnie z ówczesną ideologią - prawa i obowiązki obywateli.

\section{Summary}

\section{The Small Constitution of 1947 - its origin and value}

The paper discusses the patterns and some details of the Constitutional Act of $19^{\text {th }}$ February 1947 on the system and scope of activity of the supreme organs of the Republic of Poland, which is also called the Small Constitution of 1947. The Small Constitution being a 65 year - old law is still under the historians and constitutional law scholars scrutiny and appraisal. 
In the light of certain studies it seems that this Act, previously read as an attempt to combine traditional democratic principles with the newly adopted communist rules of government, was more facade and a pretense than a true democratic device.

It adopted the separation of powers principle and parliamentary rule (the parliamentary cabinet model). Despite the fact that the Small Constitution incorporated many provisions directly from the March Constitution of 1921, the scope of their legal and practical modification led to their distortion. The position and competences of the Legislative Sejm, the President, and the newly established Council of State were inconsistent with the separation of powers and the parliamentary system of government, as well. The detailed responsibilities of the Sejm, Council of State, the President opened the way to adoption of Soviet Union model of government. Thus, the role of the Small Constitution was to legitimize a communist authority and not to limit its powers.

The same is true when we focus on the citizens rights and freedoms. The Declaration of realization of citizen rights and freedoms of February $22^{\text {nd }}$ 1947 did not create the legal standards and guaranties of individual freedoms and rights. On the contrary, the constitutional status of individual was the result of current legislation.

Under the rule of the Small Constitution, because of its temporary and incomplete nature, the "new authority" paved the way to enactment of the Constitution of 1952 modeled after the Stalin constitution. 